Ann. Biol. anim. Bioch. Biophys., 1979, 19 (3 A), 573-581.

\title{
Developmental changes in lipogenic enzyme activities in liver and adipose tissue of post-weaning rats. Effect of sex and castration
}

par G. GANDEMER, G. PASCAL, G. DURAND

Station de Recherches de Nutrition, INRA, 78350 Jouy-en-josas, France.

Summary. The specific activities of acetyl-CoA-carboxylase, malic enzyme (decarboxylating) and glucose-6-P dehydrogenase were determined in the liver and adipose tissues of rat. At weaning, Wistar CF rats were divided into 4 groups (males, females, castrated males, castrated females) and fed a low fat diet ad libitum. Eight animals of each group were killed at different ages $(25,36,42,50$ and 70 days). The results of the study showed that :

- in both sexes as well as in castrated animals, the adipose tissue was the site of intense lipogenesis between weaning and 50 days, but that its lipogenic capacity declined during adulthood ;

- nevertheless, as compared to adipose tissue, the liver might play a considerable role in de novo fatty acid synthesis, i. e. acetyl-CoA-carboxylase activity of the liver represented at least 70 p. 100 of the whole « liver + perirenal and subcutaneous adipose tissue » activity ; - the differences in acetyl-CoA-carboxylase activity caused by aging might account for the variations in adiposity of the 4 groups of animals between weaning and 50 days; - sex and castration had a weak effect on the activity pattern of the 3 enzymes studied in the adipose tissue. On the other hand, the effect of sex and castration was evident in the liver, especially after 50 days.

\section{Introduction.}

During the last decade many studies on de novo lipogenesis have been done in rats (Chakrabarty and Leveille, 1968, 1969 ; Taylor et al., 1967 ; Webb and Bailey, 1975), mice (Smith and Abraham, 1970), pigs (Anderson and Kauffman, 1973), rabbits (Smith, 1975), ruminants (Ingle et al., 1972), humans (Patel ef al., 1975) and birds (Goodridge and Ball, 1967). These reports measured the activities of the main lipogenic enzymes, i. e. acetyl-CoA-carboxylase, ATP-citrate lyase, malic enzyme and glucose-6-P dehydrogenase in the liver (Taylor ef al., 1967 ; Webb and Bailey, 1975) or the adipose tissue (Anderson and Kauffman, 1973) at different developmental stages. These enzyme activities have also been studied simultaneously in the liver and the adipose tissue (Chakrabarty and Leveille, 1968, 1969) at only one stage of development. To our knowledge, only Pascal ef al. (1977) followed lipogenesis in the liver 
and the adipose tissue simultaneously during the growth of male rats. Their results showed a peak of lipogenic enzyme activity at the age of 6 weeks and emphasized the preponderant role played by the liver in de novo fatty acid synthesis. Nevertheless, their conclusions were based on the assay of only one enzyme, acetyl-CoA-carboxylase, in male rats.

In the present work, the pattern of de novo lipogenesis was followed concomitantly in the liver and the perirenal and subcutaneous adipose tissues during the growth of intact and castrated male and female rats. De novo fatty acid synthesis was assessed by the assay of acetyl-CoA-carboxylase, the key enzyme of this metabolic pathway (Rous, 1977). Malic enzyme and glucose-6-P dehydrogenase were also assayed ; they supplied an important part of the necessary NADPH for fatty acid synthesis (Kornacker and Ball, 1965). The activities of these two dehydrogenases have been highly correlated $(P<0.02)$ with the lipogenic capacity of adipose tissue in vitro (Leveille, 1972).

\section{Material and methods.}

\section{Animals.}

148 male and female Wistar CF rats were reared in litters of 8 . After weaning at 21 days, the animals were divided into 4 groups (intact males, intact females, castrated males and castrated females) ; 4 to 6 lots of 8 to 10 animals each were constituted in each group. The castrated animals were operated when between 21 and 25 days old; intact males and females were sham-operated at the same time. The animals were individually housed in a room with controlled light ( $7 \mathrm{a} . \mathrm{m}$. to $7 \mathrm{p}$. m.), temperature $\left(22{ }^{\circ} \mathrm{C}\right)$ and humidity ; they were fed a semi-synthetic diet ad libitum composed of : casein 22 p. 100, carbohydrates 71 p. 100 (1/3 sucrose, 2/3 starch), corn oil 0.3 p. 100, vitaminized mixture 1 p. 100 , mineral mixture 4 p. 100 , cellulose 2 p. 100 and DL methionine 0.16 p. 100.

Eight to 10 animals were killed in each group by decapitation af $19,25,36,42,50$ and 70 days. These ages corresponded to a male rat body weight of $40,50,100,150$, 200 and $300 \mathrm{~g}$, respectively. Two lats of males and females were studied at 19 and 25 days. After the rats were killed, the liver and the subcutaneous and perirenal adipose tissues were quickly removed, weighed and stored at $-80^{\circ} \mathrm{C}$. Weight gain and feed intake of the rats of the 4 lots killed at 70 days were recorded daily; only weight gain was monitored in the other lots.

\section{Enzyme assays.}

The homogenates were prepared using the previously described technique of Pascal ef al. (1977). Samples of the same lot were quantitatively pooled due to weak development of the dorsal subcutaneous adipose tissue at 19 and 25 days and of perirenal adipose tissue at 19, 25, 36 and 42 days.

Acetyl-CoA-carboxylase (E.C.6.4.1.2.) (ACX) was assayed with the method of Chang ef al. (1967) modified by Chakrabarty and Leveille $(1968,1969)$. Malic enzyme (E.C.1.1.1.40) (ME) and glucose-6-P dehydrogenase (E.C.1.1.1.49) (G-6-PDH) were assayed with the methods of Fitch ef al. (1959) and Hsu and Lardy (1969), respectively. These three enzymes were assayed in the liver and the subcutaneous and peri- 
renal adipose tissues. Malic enzyme and glucose-6-P dehydrogenase specific activities were expressed in $\mu \mathrm{mol}$ of NADPH formed $/ \mathrm{min} . / \mathrm{g}$ of wet tissue at $37^{\circ} \mathrm{C}$; those of acetyl-CoA-carboxylase were shown in $\mu \mathrm{mol}$ of $\mathrm{HCO}_{3}^{-}$incorporated $/ \mathrm{min} . / \mathrm{g}$ of wet tissue at $37^{\circ} \mathrm{C}$.

Statistics. - Using the t-test, the means were compared in tables 1 and 2 ; the effect of animal type on specific liver and adipose tissue activities was studied by variance analysis. The method of Snedecor (1956) was used for all computations.

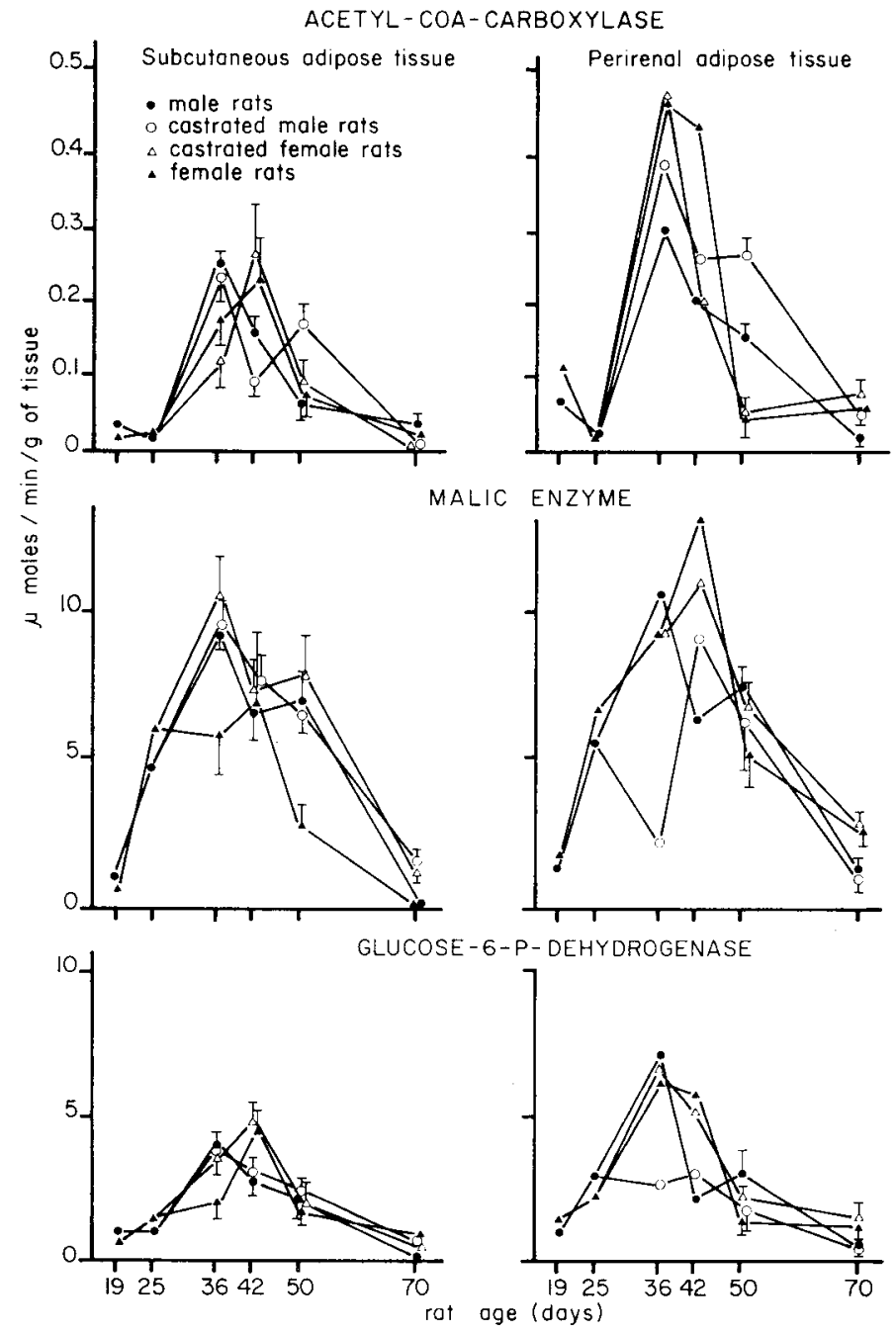

FIG. 1. - Developmental changes in the activity of acetyl-CoA-carboxylase, malic enzyme, glucose-6-P dehydrogenase in subcutaneous and perirenal adipose tissues in male, female and castrated male and female rats. The enzyme activities are expressed as $\mu \mathrm{mol} / \mathrm{g}$ wet wt of adipose tissue at $37^{\circ} \mathrm{C}$. Each point is the mean \pm SEM of 8 or 10 animals. 


\section{Results and Discussion.}

Weight gain and food intake.

The results shown in table 1 concern the 4 lots of rats killed at 70 days. During post-weaning development, the growth rate of the castrated males and females remained similar to and intermediate between those of the intact males and females. These results were similar to those obtained by Slob and Van Der Verff Ten Bosch (1975) and Bell and Zucker (1971). Castration at 25 days did not completely obliterate sexual differences which were partly determined in the perinatal period and/or in the 10 days after birth (Grady ef al., 1965). Table 2 shows body weight and liver and adipose tissue weight of the different lots.

Pattern of enzyme activity in adipose tissue and liver.

The activities of ACX, ME, G-6-PDH in the adipose tissue (fig. 1) were characterized by :

- low values in the period immediately before and after weaning (19 to 25 days) ;

- a very marked peak at 36 or 42 days, then a drop to low values at adulthood (70 days). Anderson and Kauffman (1973) observed a similar pattern in the adipose tissues of castrated pigs. Our results obtained with $\mathrm{ACX}, \mathrm{ME}$ and G-6-PDH assays confirm a lipogenic activity peak as noted by Pascal ef al. (1977) when assaying lipoprotein-lipase and $A C X$ in the adipose tissue of male rats. The present study extends these results obtained in male rats to females and castrates of both sexes. Specific enzyme activities were higher in the perirenal adipose tissue than in the dorsal subcutaneous tissue. These variations in adipose tissue lipogenic capacity depending upon localization have already been observed in rats (Benjamin ef al., 1961), pigs (Anderson et al., 1972) and ruminants (Ingle et al., 1972).

The low activity of the 3 enzymes in the liver (fig. 2) of suckling rats significantly increased at weaning. Ballard and Hanson (1967) suggested that this elevation of enzymatic activities at weaning was related to the change from a lipid-rich milk diet to a carbohydrate-type diet. This hypothesis was confirmed by Lockwood ef al. (1970) in rats and by Smith and Abraham (1970) in mice. They showed that early weaning with a lipid-free diet prematurely activated liver lipogenic activity. However, Taylor et al. (1967) reported that nutritional factors alone were not responsible for the observed enzymatic changes. ACX, ME and G-6-PDH activity curves were similar to those already described by Lockwood et al. (1970) and Webb and Bailey (1975). Depending on the type of animal, the rise in hepatic enzyme activity was strongly reduced between 36 and 50 days of age. Adipose tissue lipogenic activity was at a peak during this period. The same processes were reported between 40 and 50 days in the specific activity curves of ATP citrate lyase and pyruvate kinase by Webb and Bailey (1975).

\section{Effect of sex and castration.}

Sex and castration had a weak effect on the activity pattern of the three enzymes studied in the adipose tissue. Variance analysis did not reveal significant differences between the 4 groups of animals, no matter what the stage of development or the adi- 
TABLE 1

Effect of sex and castration on food intake, body weight gain and consumption index

Periods

\begin{tabular}{|c|c|c|c|c|c|}
\hline Sex & & 25-35 days & 36-42 days & 43-50 days & $51-70$ days \\
\hline Males & $\begin{array}{l}\text { Food intake (g/day) } \ldots \ldots \ldots \ldots \\
\text { Weight gain (g/day) } \ldots \ldots \ldots \ldots \\
R=\text { Food intake/Weight gain }\end{array}$ & $\begin{array}{l}13.4 \pm 0.5\left({ }^{1}\right)^{a} \\
6.0 \pm 0.3^{a} \\
2.23 \pm 0.07^{a}\end{array}$ & $\mid \begin{array}{l}17.6 \pm 0.6^{a} \\
6.3 \pm 0.3^{a} \\
2.80 \pm 0.06^{a}\end{array}$ & $\left|\begin{array}{rl}20.4 & \pm 0.7 a \\
6.7 \pm 0.3^{a} \\
3.04 \pm 0.07^{a}\end{array}\right|$ & $\begin{aligned} & 22.0 \pm 0.5^{a} \\
& 6.2 \pm 0.2^{a} \\
& 3.58 \pm 0.10^{a}\end{aligned}$ \\
\hline $\begin{array}{c}\text { Castrated } \\
\text { males }\end{array}$ & $\begin{array}{l}\text { Food intake }(g / \text { day) } \ldots \ldots \ldots \ldots \\
\text { Weight gain (g/day) } \ldots \ldots \ldots \ldots \\
R \ldots \ldots \ldots \ldots \ldots\end{array}$ & $\mid \begin{aligned} 12.7 & \pm 0.6^{b} \\
5.3 \pm 0.2^{b} & \pm 0.07^{a}\end{aligned}$ & $\begin{aligned} 16.0 & \pm 0.4^{b} \\
6.0 & \pm 0.2^{a b} \\
2.68 & \pm 0.05^{a}\end{aligned}$ & $\left|\begin{array}{l}17.7 \pm 0.3^{b} \\
5.4 \pm 0.2^{b} \\
3.34 \pm 0.12^{b}\end{array}\right|$ & $\begin{array}{l}18.8 \pm 0.5^{b} \\
4.5 \pm 0.2^{b} \\
4.22 \pm 0.10^{b}\end{array}$ \\
\hline $\begin{array}{l}\text { Castrated } \\
\text { females }\end{array}$ & $\begin{array}{l}\text { Food intake (g/day) } \\
\text { Weight gain (g/day) } \\
\text { R ................. }\end{array}$ & $\mid \begin{aligned} & 13.6 \pm 0.4^{b} \\
& 5.2 \pm 0.2^{b} \\
& 2.61 \pm 0.06^{b}\end{aligned}$ & $\mid \begin{aligned} 17.3 & \pm 0.2^{a} \\
5.8 & \pm 0.1^{b} \\
3.01 & \pm 0.07^{b}\end{aligned}$ & $\left|\begin{array}{r}18.7 \pm 0.4^{c} \\
4.9 \pm 0.3^{b} \\
3.96 \pm 0.25^{c}\end{array}\right|$ & $\begin{aligned} & 19.5 \pm 0.5^{b} \pm 0.1^{b} \\
& 4.4 \pm 0.50 \pm 0.15^{b}\end{aligned}$ \\
\hline Females & $\begin{array}{l}\text { Food intake (g/day) } \\
\text { Weight gain }(g / \text { day }) \ldots \\
R \ldots \ldots \ldots \ldots \ldots\end{array}$ & $\begin{array}{l}12.1 \pm 0.3^{c} \\
4.7 \pm 0.1 c \\
2.62 \pm 0.07^{b}\end{array}$ & $\begin{array}{c}15.4 \pm 0.4^{b} \\
4.1 \pm 0.2^{c} \\
3.77 \pm 0.25^{c}\end{array}$ & $\left|\begin{array}{l}16.2 \pm 0.6^{b} \\
3.2 \pm 0.2^{c} \\
5.18 \pm 0.53^{a}\end{array}\right|$ & $\begin{array}{c}17.1 \pm 0.5^{c} \\
2.9 \pm 0.1^{c} \\
5.95 \pm 0.18^{c}\end{array}$ \\
\hline
\end{tabular}

( $\left.{ }^{1}\right)$ Mean \pm SEM - Results followed by different superscripts differ significantly $(p<0.05)$. All the results are computed on the 4 lots killed at 70 days.

TABLE 2

Body, liver and adipose tissues weights of the animals

\begin{tabular}{|c|c|c|c|c|c|c|c|c|}
\hline \multirow{2}{*}{ Sex } & \multirow{2}{*}{$\begin{array}{l}\text { Weight } \\
\text { (g) }\end{array}$} & \multicolumn{7}{|c|}{ Age of rats (days) } \\
\hline & & $\begin{array}{c}19 \\
(10)\left({ }^{1}\right)\end{array}$ & & $\begin{array}{c}25 \\
(10)\end{array}$ & $\begin{array}{l}36 \\
(8)\end{array}$ & $\begin{array}{l}42 \\
(8)\end{array}$ & $\begin{array}{l}50 \\
(8)\end{array}$ & $\begin{array}{l}70 \\
(8)\end{array}$ \\
\hline Males & \begin{tabular}{|l} 
Body \\
Liver \\
SC-AT ( $\left.{ }^{3}\right)$ \\
PAT $\left(^{4}\right)$
\end{tabular} & $\mid \begin{array}{ll}43 & \pm 1\left({ }^{2}\right)^{a} \\
1.61 & \pm 0.08^{a} \\
0.67 & \pm 0.03^{a} \\
0.100 \pm 0.003^{a}\end{array}$ & $\begin{array}{l}55 \\
2.17 \\
0.62 \\
0.11\end{array}$ & $\begin{array}{l} \pm 1 a \\
\pm 0.08 a \\
\pm 0.07^{a} \\
\pm 0.01^{a}\end{array}$ & $\begin{aligned} & 110 4^{a} \\
& 5.62 \pm 0.23 a \\
& 1.32 \pm 0.09 a \\
& 0.25 \pm 0.04 b\end{aligned}$ & $\mid \begin{array}{r}155 \pm 4^{a} \\
7.94 \pm 0.28 a \\
2.76=0.24 a \\
0.96 \pm 0.09 a\end{array}$ & $\left|\begin{array}{l}206 \pm 7^{a} \\
10.05 \pm 0.38 a \\
4.32 \pm 0.25 a \\
1.64 \pm 0.13^{a}\end{array}\right|$ & $\begin{array}{r}322 \pm 8^{a} \\
12.48 \pm 0.23 \\
9.37 \pm 0.80 \\
6.24 \pm 0.52\end{array}$ \\
\hline $\begin{array}{c}\text { Castrated } \\
\text { males }\end{array}$ & \begin{tabular}{|l} 
Body \\
Liver \\
SC-AT \\
PAT
\end{tabular} & & & & $\mid \begin{array}{r}111 \pm 2^{a} \\
5.51 \pm 0.20^{a} \\
1.65 \pm 0.10^{b} \\
0.38 \pm 0.03^{a}\end{array}$ & $\mid \begin{array}{r}150 \pm 4^{a} \\
7.03 \pm 0.21 b \\
2.76 \pm 0.12 a \\
0.94 \pm 0.11 a\end{array}$ & $\mid \begin{array}{c}184 \pm 6^{b} \\
8.19 \pm 0.33^{b} \\
3.54 \pm 0.29 b \\
1.20 \pm 0.17^{b}\end{array}$ & $\begin{array}{l}277 \pm 7^{b} \\
10.13 \pm 0.34 \\
9.98 \pm 0.78 \\
6.74 \pm 0.82\end{array}$ \\
\hline $\begin{array}{c}\text { Castrated } \\
\text { females }\end{array}$ & $\begin{array}{l}\text { Body } \\
\text { Liver } \\
\text { SC-AT } \\
\text { PAT }\end{array}$ & & & & $\left|\begin{array}{r}111 \pm 4^{a} \\
6.09 \pm 0.13^{a} \\
1.57 \pm 0.13^{b} \\
0.25 \pm 0.03^{b}\end{array}\right|$ & $\mid \begin{array}{r}137 \pm 0.6^{b} \\
6.03 \pm 0.29 c \\
1.74 \pm 0.24 b \\
0.30 \pm 0.06 b\end{array}$ & \begin{tabular}{|l|}
$170 \pm 3^{c}$ \\
$8.74 \pm 0.25 b$ \\
$2.86 \pm 0.23 c$ \\
$0.79 \pm 0.05 c$
\end{tabular} & $\mid \begin{array}{l}268 \pm 4^{b} \\
8.79 \pm 0.23 c \\
8.39 \pm 0.50 \\
3.59 \pm 0.37\end{array}$ \\
\hline Females & $\begin{array}{l}\text { Body } \\
\text { Liver } \\
\text { SC-AT } \\
\text { PAT }\end{array}$ & $\begin{array}{ll}42 & \pm 1 a \\
1.61 & \pm 0.07 a \\
0.68 & \pm 0.04 a \\
0.070 \pm 0.010^{b}\end{array}$ & $\mid \begin{array}{l}54 \\
2.17 \\
0.74 \\
0.090\end{array}$ & $\begin{array}{l} \pm 1 a \\
\pm 0.07^{a} \\
\pm 0.01^{a} \\
0 \pm 0.003^{a}\end{array}$ & $\mid \begin{aligned} & 110 \pm 2^{a} \\
& 5.71 \pm 0.15^{a} \\
& 1.74 \pm 0.08^{b} \\
& 0.29 \pm 0.03^{b}\end{aligned}$ & $\mid \begin{array}{r}130 \pm 3^{b} \\
6.24 \pm 0.15^{c} \\
1.59 \pm 0.16^{b} \\
0.32 \pm 0.05^{b}\end{array}$ & $\mid \begin{array}{c}163 \pm 2^{d} \\
7.54 \pm 0.17 c \\
2.73 \pm 0.22 c \\
0.86 \pm 0.09 c\end{array}$ & $\begin{array}{l}210 \pm 6^{c} \\
7.07 \pm 0.31 \\
4.39 \pm 0.31 \\
2.66 \pm 0.17\end{array}$ \\
\hline
\end{tabular}

(1) Number of animals in each group.

( $\left.{ }^{2}\right)$ Mean \pm SEM Results followed by different superscripts differ significantly $(P<0.05)$. Male and female rats were castrated or sham-operafed on day 23 after birth.

$\left({ }^{3}\right)$ SC-AT : Subcutaneous adipose tissue.

(') PAT : Perirenal adipose tissue. 
pose tissue studied. The lipogenic peak in rat adipose tissue between 36 and 50 days was thus not related to the change in hormone balance accompanying this developmental stage, as suggested by Pascal ef al. (1977).

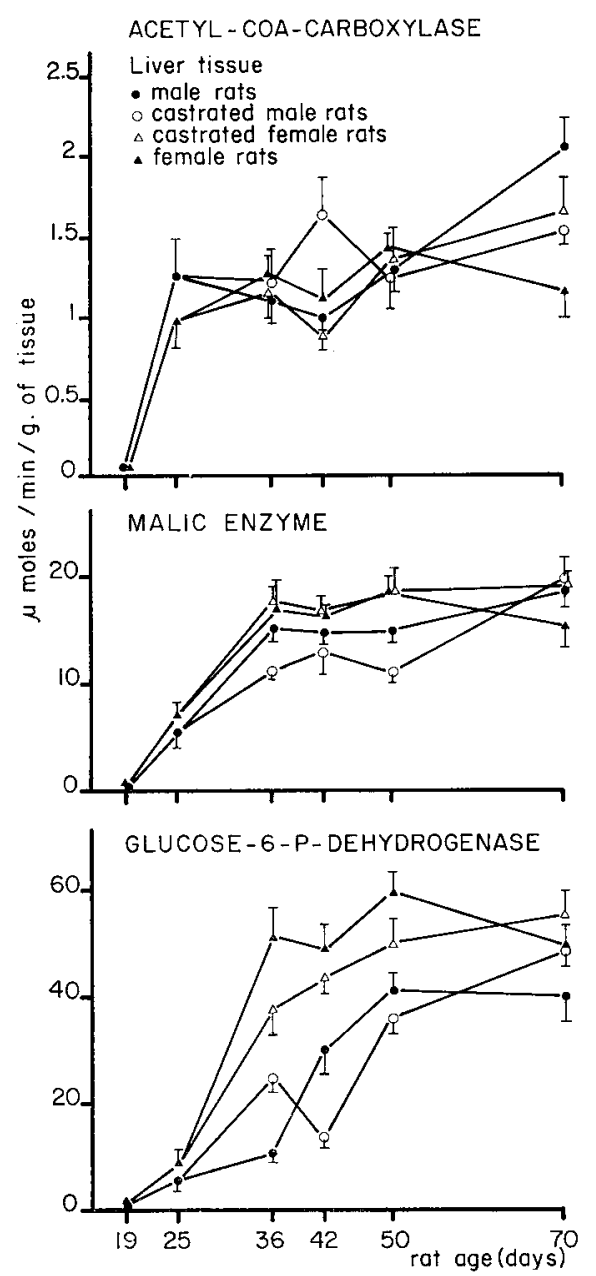

FIG. 2. - Developmental changes in the activity of acetyl-CoA-carboxylase, malic enzyme, glucose-6-P dehydrogenose in liver tissue in male, female and castrated male and female rats. The enzyme activities are expressed as $\mu \mathrm{mol} / \mathrm{g}$ wet wt of liver at $37^{\circ} \mathrm{C}$. Each point is the mean \pm SEM of 8 or 10 animals.

On the other hand, the effect of sex and castration was evident in the liver. While between weaning and 50 days of age ACX activity did not differ in the 4 groups of animals, the activity of the two dehydrogenases was higher in intact and castrated females than in comparable males. Lockwood ef al. (1970) have already shown these differences between the 4 types of animals at 50 days. Taylor et al. (1967) at 35 days and Webb and Bailey (1975) at 50 days for G-6-PDH and at 180 days for ME, emphasized the same variations befween males and females. 
At 70 days, there were wide differences in ACX hepatic activity in the 4 types of animals. The 2 types of castrates had very similar activities intermediate between those of males and females. Between 50 and 70 days, the females had a lower body weight gain and lipid accumulation than the other animals; this may explain the lower hepatic lipogenic capacity. During the same period, the males stored less fat than the castrates, while hepatic ACX activity was higher. This observation may be explained by the fact that the castrates had a lower overall energy loss and thus probably less intense lipid catabolism, which might lead to more fat storage although lipogenic capacity was lower.

Relative importance of liver and adipose tissue in de novo lipogenesis.

For a given tissue, the mode of expressing enzymatic activity in $\mathrm{mg}$ of supernatant protein, in $\mathrm{g}$ of wet tissue, in total tissue or $10^{6}$ cells does not basically alter the curves of the enzyme patterns (Anderson and Kauffman, 1973). However, these authors reported elsewhere (Anderson et al., 1972) that the proportion of the enzyme activities of various adipose tissues varied with the mode of data expression. Also, a comparison of hepatic and adipose tissue lipogenic enzyme activities would greatly depend on their mode of expression since $1 \mathrm{~g}$ of liver gives 80 to $100 \mathrm{mg}$ of supernatant protein, while $1 \mathrm{~g}$ of adipose tissue gives 5 to $10 \mathrm{mg}$. Therefore, to determine the relative importance of liver and adipose tissue in de novo lipogenesis, we have expressed enzyme activity in the whole tissue or organ. The total activity of the three enzymes studied may be easily computed from specific activity curves (figs. 1,2) and from adipose tissue and liver weights (table 2).

The lipogenic capacity of the whole of the adipose tissue was estimated by taking the mean of the enzyme activities of the two adipose tissues studied as the specific activity of each of the three enzymes, and the whole of the dissectable white adipose tissue as the mass. Based on these assumptions, our results show that :

- between weaning and 50 days of age, the adipose tissues may represent between 20 and 30 p. 100 of the whole « liver + adipose tissue », while at 70 days, they represent 5 to 10 p. 100 ;

- the liver would play a considerable role as compared to the adipose tissue in de novo fatty acid synthesis. While previous studies (Favarger, 1965 ; Hausberger ef al., 1954) reached the opposite conclusion, recent results (Hems et al., 1975 ; Masoro, 1977) agree with ours. However, it must be remembered that our assumptions do not take into consideration the differences in the lipogenic capacity of the adipose tissue in relation to its localization (Benjamin et al., 1961 ; Anderson et al., 1972 ; Ingle et al., 1972). Moreover, none of these studies take into account the lipogenic capacity of other organs, such as the intestine, kidneys, lungs, skin and muscle which may play a large part in de novo lipogenesis (Favarger, 1965).

Although enzyme activities only represent potentialities and not true synthesizing abilities in vivo, a comparison of the whole of the total hepatic and adipose tissue $A C X$ activities indicates different adipose tissue development in the 4 types of animals between weaning and 50 days of age. However, it is difficult to draw definitive conclusions as to the relative importance of the liver and the adipose tissue in de novo lipo- 
genesis since they are based solely on the activity of three enzymes of this metabolic pathway. Further study using fatty acid labelling $\left({ }^{3} \mathrm{H} 2 \mathrm{O}\right.$, glucose $\left.-{ }^{14} \mathrm{C}\right)$ in vivo should elucidate this point.

Reçu en oout 1978.

Accepté en novembre 1978.

Résumé. Les activités spécifiques de l'acétyl-CoA-carboxylase, de l'enzyme malique (décarboxylante) et de la glucose-6-P-déshydrogénase ont été mesurées dans le foie et le tissu adipeux du rat. Des rats Wistar CF ont été divisés au sevrage en 4 groupes (males, femelles, males et femelles castrés) et alimentés ad libitum, avec un régime pauvre en lipides $(0,3$ p. 100). Huit animaux de chaque groupe sont sacrifiés aux âges successifs de $25,36,42$, 50,70 jours.

Les résultats obtenus montrent que :

- quel que soit le type d'animal, les tissus adipeux sont le siège d'une lipogenèse très intense entre le sevrage et l'âge de 50 jours ; par contre, leur capacité lipogénique est faible à 70 jours ;

- le foie joue cependant un rôle primordial dans la synthèse de novo des acides gras, comparativement aux tissus adipeux étudiés : au moins 70 p. 100 de l'activité totale de l'ACX de l'ensemble : «foie + tissus adipeux périrénal et sous-cutané dorsal 》;

- entre le sevrage et l'âge normal de la puberté, les différences d'état d'engraissement des 4 types d'animaux peuvent s'expliquer par des différences d'activité de l'ACX dans les tissus ou organe considérés ;

- l'influence du sexe et de la castration sur les activités des 3 enzymes étudiées est faible dans le tissu adipeux, alors qu'elle apparaît nettement dans le foie, principalement après l'âge de 50 jours.

\section{References}

ANDERSON D. B., KAUFFMAN R. G., 1973. Cellular and enzymatic changes in porcine adipose tissue during growth. J. Lipid Res., 14, 160-168.

ANDERSON D. B., KAUFFMAN R. G., KASTENSCHMIDT L. L., 1972. Lipogenic enzyme activities and cellularity of porcine adipose tissue from various anatomical localizations. J. Lipid Res., 13, 593-599.

BALLARD F. J., HANSON R. W., 1967. Changes in lipid synthesis in rat liver during development. Biochem. J., 102, 952-958.

BELL D. D., ZUCKER I., 1971. Sex differences in body weight and eating organization and activation by gonadal hormones in the rat. Physiol. Behav., 7, 27-34.

BENJAMIN W., GELLHORN A., WAGNER M., KUNDEL M., 1961. Effect of aging on lipid composition and metabolism in the adipose tissues of the rat. Am. J. Physiol., 201, 540-546.

CHAKRABARTY K., LEVEILLE G. A., 1968. Influence of periodicity of eating on the activity of various enzymes in adipose tissue, liver and muscle in the rat. J. Nutr., 96, 76-82.

CHAKRABARTY K., LEVEILLE G. A., 1969. Acetyl-CoA-carboxylase and fatty acid synthetase activities in liver and adipose tissue of meal fed Rats. Proc. Soc. exp. Biol. Med., 131, 1051-1054.

CHANG H. C., SEIDMAN I., TEEBOR G., LANE M. D., 1967. Liver acetyl-CoA-carboxylase and fatty acid synthefase : relative activities in the normal state and in hereditary obesity. Biochem. Biophys. Res. Com., 28, 682-686.

FAVARGER P., 1965. Relative importance of different tissues in the synthesis of fatty acids. In : RENOLD A. E., CAHILL G. F. Handbook of physiology : Sect. 5, Adipose tissue. Washington D. C., Am. physiol. Soc., chap. 4, 19-24.

FITCH W. H., HILL R., CHAIKOFF I. L., 1959. The effect of fructose feeding on glycolytic enzyme activities of the normal rat liver. J. biol. Chem., 234, 1048-1051.

GRADY K. L., PHOENIX C. H., YOUNG W. C., 1965. Rôle of the developing rat testis in differentiation of the neural tissue mediating mating behaviour. J. comp. physiol. Psychol., 59, 176-182. 
GOODRIDGE A. G., BALL E. G., 1967. Lipogenesis in pigeon : in vivo studies. Am. J. Physiol., 213, 245-249.

HAUSBERGER F. X., SEYMOUR W. H., RUTMAN R. J., 1954. The influence of insulin on glucose utilization in adipose and hepatic tissues in vitro. J. biol. Chem., 208, 431-438.

HEMS D. A., RATH E. A., VERRINDER T. R., 1975. Fatty acid synthesis in liver and adipose tissue of normal and genetically obese (ob/ob) mice during the 24 hours cycle.B iochem. J., 150, 167-173.

HSU R. Y., LARDY H. A., 1969. Malic enzyme, 230-235. In LOWENSTEIN J. M., Methods in enzymology, Vol. 17, Acad. Press, New-York and London.

INGLE D. L., BAUMAN D. E., GARRIGUS U. S., 1972. Lipogenesis in the ruminant in vitro study of tissue sites, carbon source and reducing equivalent generation for fatty acid synthesis. $J$. Nutr., 102, 609-616.

KORNACKER M. S., BALL E. G., 1965. Citrate cleavage in adipose tissue. Proc. nat. Acad. Sci., U.S.A., 54, 899-904.

LEVEILLE G. A., 1972. The long term effects of meal eating on the lipogenesis, enzyme activity and longevity in the rat. J. Nutr., 102, 549-556.

LOCKWOOD E. A., BAILEY E., TAYLOR C. B., 1970. Factors involved in changes in hepatic lipogenesis during development of the rat. Biochem. J., 118, 155-162.

MASORO E. J., 1977. Lipids and lipid metabolism. Annu. Rev. Physiol. (Palo Alto California, U.S.A.), 39, 301-321.

PASCAL G., DURAND G., MACAIRE J. P., PENOT E., 1977. Evolution de l'activité de l'acétyl-CoAcarboxylase et de la lipoprotéine lipase dans le foie et les tissus adipeux du rat mâle au cours du développement après sevrage. Influence du taux de lipides de la ration. Ann. Biol. anim. Bioch. Bicphys., 17, 827-849.

PATEL M. S., OWEN O. E., GOLDMAN L. I., HANSON R. W., 1975. Fatty acid synthesis by human adipose tissue. Mefabolism, 24, 161-173.

ROUS S., 1977. Regulation of lipolytic and lipogenic enzyme activity in adipose tissue. Ann. Biol. anim. Bioch. Biophys., 17, 807-826.

SLOB A. K., VAN DER WERFF TEN BOSCH J. J., 1975. Sex differences in body growth in the rat. Physiol. Behav., 14, 353-361.

SMITH S., 1975. Lipogenesis in rabbit adipose tissue. J. Lipid Res., 16, 324-331.

SMITH S., ABRAHAM S., 1970. Fatty acid synthesis in developping mouse liver. Arch. Biochem. Biophys., 136, 112-121.

SNEDECOR G. W., 1956. Statistical methods (Ed. 5, lowa State Univ. Press, Ames, lowa).

TAYLOR C. B., BAILEY E., BARTLEY W., 1967. Changes in hepatic lipogenesis during development of the rat. Biochem. J., 105, 717-722.

WEBB J. R., BAILEY E., 1975. Changes in activities of some enzymes associated with hepatic lipogenesis in the rat from weaning to old age and effect of sucrose feeding. Int. J. Biochem., 6, 813819. 